\title{
Investigation of agrobiological properties of $c t b$ (cholera toxin B subunit) transgenic tomato under in vivo condition
}

Nguyen Hoang Loc*, Le Thi Thinh

Institute of Bioactive Compounds, University of Sciences, Hue University, Hue 530000, Vietnam

\begin{abstract}
Received:
Jan 10, 2020

Accepted:

May 21, 2020

Published:

July 30,2020

\section{Abstract}

The study aimed to evaluate some agrobiological properties of $c t b$ transgenic tomatoes under in vivo condition through physiological and biochemical characteristics relate to fruit yield and quality. Agrobiological parameters are determined by weighing, measuring and counting. Photosynthetic rate was determined via uptake carbon dioxide, the spectrophotometric method used to measure chlorophyll and total carotenoid content, vitamin $\mathrm{C}$ was determined using the iodine titration method, reducing sugar was determined by dinitrosalicylic acid, degree Brix was measured using an ATAGO N1 refractometer and total acidity in fruit juice was determined by neutralization method. Study results showed that final harvesting time for all tomatoes were 150 days including transgenic plants and control. Plant height (cm) ranged from 80.3 to 83.6 , number of compound leaves from 17.6 to 22 , and number of inflorescences from 7.3 to 9.3 . The chlorophyll content $(\mathrm{mg} / \mathrm{g})$ and the photosynthetic rate $\left(\mu \mathrm{M} \mathrm{CO} / \mathrm{m}^{2} / \mathrm{s}\right)$ peaked at young fruit stage in both transgenic plants and control with values from 0.48 to 0.62 and from 9.08 to 16.77 , respectively. The yield, yield components and fruit shape of transgenic plants and control were also similar. Number of fruits ranged from 14.6 to 23, fruit weight $(\mathrm{g})$ ranged from 61.5 to 69.3 , and individual yield $(\mathrm{kg})$ varied from 0.99 to 1.53 . The main biochemical characteristics of transgenic plants and control were not different, dry matter (\%) accounts for 5.45-5.91, reducing sugar $(\%)$ of $1.87-2.22$, vitamin $\mathrm{C}(\mathrm{mg} / 100 \mathrm{~g})$ of 44.01-46.13, acidity (\%) of 0.62-0.89, Brix (\%) of 5.23-6.01 and carotene $(\mathrm{mg} / 100 \mathrm{~g})$ of 3.01-3.84. In conclusion, six $c t b$ transgenic tomato individuals were able to grow normally under in vivo conditions similar to non-transgenic control plants. Agrobiological properties between transgenic plants and control were insignificantly different with $p>0.05$.
\end{abstract}

Keywords: Cholera toxin B subunit (CTB), In vivo ctb transgenic tomato, Lycopersicon esculentum, Vibrio cholerae

\section{How to cite this:}

Nguyen Hoang Loc and Le Thi Thinh, 2020. Investigation of agrobiological properties of $c t b$ (cholera toxin B subunit) transgenic tomato under in vivo condition. Asian J. Agric. Biol. 8(3): 308-314. DOI: https://doi.org/10.35495/ajab.2020.01.027

This is an Open Access article distributed under the terms of the Creative Commons Attribution 3.0 License. (https://creativecommons.org/licenses/by/3.0), which permits unrestricted use, distribution, and reproduction in any medium, provided the original work is properly cited. 


\section{Introduction}

Tomato (Lycopersicon esculentum L.) is a very nutritious fruit vegetable, have good flavors and attractive colors, so they are often used in food processing. This is an important agricultural crop with a global productivity in 2007 of about 120 million tons (Passam et al., 2007) and about 181 million tons in 2017 as reported by FAO (2019, with date reference on May $\left.1^{\text {st }}, 2019\right)$. Tomatoes contain ingredients that have high nutritional values, such as potassium, folate, vitamin $\mathrm{C}$, carotenoids (lycopene, $\beta$-carotene, $\gamma$-carotene, phytoene and phytosterols), flavonoids, vitamin $\mathrm{E}$ and some water-soluble vitamins (Beecher, 1998).

In past years, some studies used tomato as a plant host for expression of antigen proteins to produce vaccines for human and animal such as proteins that cause plague and pneumonia (Alvarez et al., 2006), hepatitis B surface antigen (HbsAg) (Srinivas et al., 2008), human immunodeficiency virus (HIV) antigen, protein $\mathrm{N}$ of rabies virus (Perea-Arango et al., 2008), cholera toxin B subunit of Vibrio cholerae (CTB) (Loc et al., 2011), antigenic polypeptide containing epitopes of the diphtheria, pertussis and tetanus exotoxins (Soria-Guerra et al., 2007), malaria antigen (PfCP-2.9) (Kantor et al., 2013), E. coli heatlabile enterotoxin B subunit (LTB) (Loc et al., 2014). However, there has been little research on the agronomic characteristics of transgenic tomato plants planted natural condition (Prematilake et al., 2002; Shah et al., 2015).

In some species, transgenic plants were evaluated for a number of field trials such as Arabidopsis thaliana and tobacco (Lieman-Hurwitz et al., 2003), rice (Chen and $\mathrm{Xu}, 2007$ ), tobacco and cotton (Rawat et al., 2011), tobacco (Wang et al., 2012), cucumber (Kiełkiewicz et al., 2012), pea (Reinecke et al., 2013), watercress (Loc et al., 2015). This work, therefore, aims to investigate the physiological and biochemical characteristics related to yield and fruit quality of $c t b$ transgenic tomatoes, a gene encoding the CTB antigen which is a potential candidate for cholera vaccine, to evaluate their growth and development under in vivo condition.

\section{Material and Methods}

\section{Plant materials}

Six $c t b$ transgenic tomato (L. esculentum L. cv. 311) individuals through Agrobacterium tumefaciens- mediated transformation from a previous study (Loc et al., 2011) were used to evaluate their growth and development under in vivo condition. 180 transgenic plants ( 6 types of individuals $\times 30$ plants of each type) grow normally under in vitro conditions with healthy roots have been planted in pots containing the ratio of 2 part of sandy soils, 1 part of coconut fiber and 2 parts of bio-compost, and placed in a net house for study. The distance from one pot to another was 60 $\mathrm{cm}$. The farming techniques, including the uniformity of biological materials, were applied evenly for all. Thirty in vitro non-transgenic tomato (L. esculentum L. cv. 311) plants were used as the control.

Tomato cultivar 311 was supplied by Dai Dia Co. Ltd. (Vietnam). This is a heat-tolerant tomato cultivar that can be grown year round. The fruits are round and flattened, weight of 90-100 g/fruit, firm and thick flesh. Seedlings 20-25 days old can be planted. Time to start harvesting is 60 days after planting.

\section{Physiological characteristics}

The growth and development of tomato plants were split into five stages including branching, flowering, fruiting, first and final harvest for evaluation. In addition, data on plant height, number of compound leaves and inflorescences were also collected.

Total chlorophyll content of leaf was determined using the spectrophotometric method as described by $\mathrm{Li}$ et al. (2018) with a slight modification. In brief, $0.1 \mathrm{~g}$ fresh leaves were extracted with $95 \%$ ethanol, the filtrate was then used to measured chlorophyll at wavelengths of 649 and $665 \mathrm{~nm}$. The contents of chlorophyll a and chlorophyll $\mathrm{b}$ were calculated as following equations (Lichtenthaler and Buschmann, 2001):

Chlorophyll a $(\mu \mathrm{g} / \mathrm{mL})=13.36 \times \mathrm{A}_{665}-5.19 \times \mathrm{A}_{649}$ Chlorophyll $\mathrm{b}(\mu \mathrm{g} / \mathrm{mL})=27.43 \times \mathrm{A}_{649}-8.12 \times \mathrm{A}_{665}$ Where: $\mathrm{A}_{649}$ and $\mathrm{A}_{665}$ are absorbances of extract at 649 and $665 \mathrm{~nm}$. Chlorophyll content $(\mu \mathrm{g} / \mathrm{mL})$ was then converted to $\mathrm{mg} / \mathrm{g}$ leaf.

Photosynthetic rate (PR) was determined via uptake carbon dioxide (Field et al., 1989) using LI-6800 portable photosynthesis system, where the leaf is enclosed in a small transparent chamber. The rate of carbon dioxide fixed by the leaf is determined by measuring the change in the carbon dioxide concentration of the air flowing across the chamber.

\section{Biochemical characteristics}

Tomato fruits were used to analyze some biochemical characteristics related to their quality. Total 
carotenoid content was determined by the spectrophotometric method. Leaf extract was prepared as for chlorophyll and carotenoid calculated as follows (Lichtenthaler and Buschmann, 2001):

Carotenoid $(\mu \mathrm{g} / \mathrm{mL})=\left(1000 \times \mathrm{A}_{470}-2.13 \times \mathrm{C}_{\mathrm{a}}-\right.$ $\left.97.64 \times \mathrm{C}_{\mathrm{b}}\right) / 209$

Where: $A_{470}$ is absorbance of leaf extract at $470 \mathrm{~nm}$. $\mathrm{C}_{\mathrm{a}}$ and $\mathrm{C}_{\mathrm{b}}$ are the contents of chlorophyll $\mathrm{a}$ and chlorophyll $\mathrm{b}$ which determined as described above. Carotenoid content $(\mu \mathrm{g} / \mathrm{mL})$ was then converted to $\mathrm{mg} / 100 \mathrm{~g}$ leaf.

Vitamin $\mathrm{C}$ content was determined using the iodine titration method (Njoku et al., 2011) with a slight modification. Twenty milliliters of tomato extract was added $25 \mathrm{~mL}$ of distilled water and $1 \mathrm{~mL}$ of $2 \%$ starch indicator solution. The titration was then carried out with standard iodine solution (for 100 $\mathrm{mL}: 1 \mathrm{~g} \mathrm{KI}, 53.6 \mathrm{mg} \mathrm{KIO}_{3}$ and $6 \mathrm{~mL} 3 \mathrm{M} \mathrm{H}_{2} \mathrm{SO}_{4}$ ). The endpoint of the titration occurred when permanent dark blue-black color was obtained due to the starchiodine complex. The ascorbic acid was used as the standard and the vitamin $\mathrm{C}$ content in the extract was calculated as follows:

Vitamin $\mathrm{C}(\%)=100\left(\mathrm{VI}_{\mathrm{A}} / \mathrm{VI}_{\mathrm{E}}\right)$

Where: $\mathrm{VI}_{\mathrm{A}}$ is the volume of standard iodine solution that reacts with ascorbic acid. $\mathrm{VI}_{\mathrm{E}}$ is the volume of standard iodine solution that reacts with vitamin $\mathrm{C}$ in the extract.

Reducing sugar was determined by dinitrosalicylic acid method (De Toledo et al., 2012) with a slight modification. $5 \mathrm{~g}$ tomato fruit were ground in $5 \mathrm{~mL}$ of $0.2 \mathrm{M}$ phosphate buffer $(\mathrm{pH} 7)$, the homogenate was then centrifuged at $12000 \mathrm{rpm}$ for $30 \mathrm{~min}$, and the supernatant was used for detection of reducing sugar. $0.2 \mathrm{~mL}$ of the supernatant was mixed with 1.5 $\mathrm{mL}$ of 3,5-dinitrosalicylic acid and $1.8 \mathrm{~mL}$ of doubledistilled water; the mixture was heated at $100^{\circ} \mathrm{C}$ for 5 $\mathrm{min}$, cooled at room temperature and then added double-distilled water to a final volume of $25 \mathrm{~mL}$. Reducing sugars were determined spectrophotometrically at $540 \mathrm{~nm}$ and the results were expressed as percentage of fresh weight with glucose was used as a standard.

Degree Brix was measured using an ATAGO N1 refractometer (Japan).

Total acidity in fruit juice was determined by neutralization method (Sadler and Murphy 2010). In brief, $10 \mathrm{~g}$ tomato fruit were extracted with doubledistilled water at $80^{\circ} \mathrm{C}$ for $15 \mathrm{~min}$, then filtered and brought to a volume of $250 \mathrm{~mL}$, followed by cooling at room temperature. $25 \mathrm{~mL}$ of filtrate was transferred to a new conical flask, added 3 drops of $0.1 \%$ phenolphthalein, then titrated with $0.1 \mathrm{~N} \mathrm{NaOH}$ until a light pink color was obtained. Total acidity $(\%)$ of the extract was calculated as followed:

Acidity $(\%)=100(\mathrm{~V} \times \mathrm{K}) / \mathrm{V}_{1}$

Where: $\mathrm{V}$ is the volume $(\mathrm{mL})$ of $0.1 \mathrm{~N} \mathrm{NaOH}, \mathrm{V}_{1}$ is the volume $(\mathrm{mL})$ of the extract, and $\mathrm{K}$ is the adjustment coefficient (0.0064 for citric acid).

\section{Statistical analysis}

The experiments were carried out with at least ten replicates for each type of sample $(n=10 \times 7$ sample types, 6 transgenic individuals and 1 control) and each experiment was repeated 3 times. The data were statistically treated by ANOVA (Duncan's test at 0.05) using SPSS software and expressed as the mean of repeats.

\section{Results}

\section{Physiological characteristics}

Data from Table 1 show that the growth and development stages of six $c t b$ transgenic and control plants are insignificantly different.

Table-1. Stages of growth and development (days) of ctb transgenic tomato plants compared with control (non-transgenic tomato plant)

\begin{tabular}{|c|c|c|c|c|c|}
\hline $\begin{array}{c}\text { Transgenic } \\
\text { plants }\end{array}$ & Branching & Flowering & Fruiting & $\begin{array}{c}\text { 1st } \\
\text { harvesting }\end{array}$ & $\begin{array}{c}\text { Final } \\
\text { harvesting }\end{array}$ \\
\hline 1 & 12 & 31 & 36 & 66 & 150 \\
\hline 2 & 14 & 32 & 38 & 68 & 150 \\
\hline 3 & 12 & 32 & 40 & 69 & 150 \\
\hline 4 & 16 & 31 & 38 & 68 & 150 \\
\hline 5 & 14 & 33 & 40 & 70 & 150 \\
\hline 6 & 12 & 33 & 39 & 68 & 150 \\
\hline Control & 12 & 32 & 38 & 67 & 150 \\
\hline
\end{tabular}

Their final harvest time is 150 days while the stages of branching, flowering, fruiting and first-time harvesting only differ from 1 to 2 days. Study on the growth and development characteristics of transgenic and control tomatoes at flowering time including plant height, number of compound leaves and number of inflorescences also found no significant differences. Plant height ranges from 80.3 to $83.6 \mathrm{~cm}$, compound leaf number was from 17.6 to 22 , and inflorescence number was from 7.3 to 9.3 (Table 2). 
Table-2. Characteristics of growth and development of $c t b$ transgenic tomato plants compared with control (non-transgenic tomato plant)

\begin{tabular}{|c|c|c|c|}
\hline $\begin{array}{c}\text { Transgenic } \\
\text { plants }\end{array}$ & $\begin{array}{c}\text { Plant height } \\
(\mathbf{c m})\end{array}$ & $\begin{array}{c}\text { No of compound } \\
\text { leaves }\end{array}$ & $\begin{array}{c}\text { No of } \\
\text { inflorescences }\end{array}$ \\
\hline 1 & $83.6^{\mathrm{a}}$ & $19.0^{\mathrm{b}}$ & $8.0^{\mathrm{a}}$ \\
\hline 2 & $81.0^{\mathrm{a}}$ & $18.0^{\mathrm{b}}$ & $8.0^{\mathrm{a}}$ \\
\hline 3 & $80.3^{\mathrm{a}}$ & $19.6^{\mathrm{ab}}$ & $8.3^{\mathrm{a}}$ \\
\hline 4 & $80.3^{\mathrm{a}}$ & $17.6^{\mathrm{b}}$ & $7.3^{\mathrm{a}}$ \\
\hline 5 & $82.0^{\mathrm{a}}$ & $18.6^{\mathrm{b}}$ & $7.6^{\mathrm{a}}$ \\
\hline 6 & $83.3^{\mathrm{a}}$ & $22.0^{\mathrm{a}}$ & $9.3^{\mathrm{a}}$ \\
\hline Control & $81.6^{\mathrm{a}}$ & $18.6^{\mathrm{b}}$ & $8.6^{\mathrm{a}}$ \\
\hline LSD $_{0.05}$ & 4.05 & 2.56 & 2.93 \\
\hline
\end{tabular}

Significant differences between mean values are represented by different letters in a column at confidence level of 0.05 of Duncan's test.

Table-3. Chlorophyll content (mg/g) of ctb transgenic tomato plants compared with control (non-transgenic tomato plant)

\begin{tabular}{|c|c|c|c|c|c|c|c|c|}
\hline \multirow{2}{*}{ Stages } & \multicolumn{5}{|c|}{ Transgenic plants } & \multirow{2}{*}{ Control } & LSD $_{\mathbf{0 . 0 5}}$ \\
\cline { 2 - 8 } & $\mathbf{1}$ & $\mathbf{2}$ & $\mathbf{3}$ & $\mathbf{4}$ & $\mathbf{5}$ & $\mathbf{6}$ & & \\
\hline Branching & $0.23^{\mathrm{a}}$ & $0.26^{\mathrm{a}}$ & $0.22^{\mathrm{a}}$ & $0.20^{\mathrm{a}}$ & $0.23^{\mathrm{a}}$ & $0.27^{\mathrm{a}}$ & $0.24^{\mathrm{a}}$ & 0.09 \\
\hline Flowering & $0.49^{\mathrm{bc}}$ & $0.51^{\mathrm{b}}$ & $0.45^{\mathrm{de}}$ & $0.44^{\mathrm{e}}$ & $0.47^{\text {cd }}$ & $0.53^{\mathrm{a}}$ & $0.49^{\mathrm{bc}}$ & 0.02 \\
\hline Young fruit & $0.50^{\mathrm{b}}$ & $0.60^{\mathrm{a}}$ & $0.49^{\mathrm{b}}$ & $0.48^{\mathrm{b}}$ & $0.52^{\mathrm{b}}$ & $0.62^{\mathrm{a}}$ & $0.52^{\mathrm{b}}$ & 0.05 \\
\hline $\begin{array}{c}\text { Green ripe } \\
\text { fruit }\end{array}$ & $0.46^{\mathrm{b}}$ & $0.55^{\mathrm{a}}$ & $0.46^{\mathrm{b}}$ & $0.45^{\mathrm{b}}$ & $0.49^{\mathrm{b}}$ & $0.57^{\mathrm{a}}$ & $0.48^{\mathrm{b}}$ & 0.04 \\
\hline $\begin{array}{c}\text { Red ripe } \\
\text { fruit }\end{array}$ & $0.26^{\mathrm{a}}$ & $0.24^{\mathrm{ab}}$ & $0.22^{\mathrm{b}}$ & $0.23^{\mathrm{ab}}$ & $0.22^{\mathrm{b}}$ & $0.21^{\mathrm{b}}$ & $0.22^{\mathrm{b}}$ & 0.03 \\
\hline
\end{tabular}

Significant differences between mean values are represented by different letters in a row at confidence level of 0.05 of Duncan's test.

The chlorophyll content $(\mathrm{mg} / \mathrm{g})$ of six $c t b$ transgenic plants range from 0.20 to 0.27 in branching stage (control: 0.24 ), 0.44 to 0.53 in flowering stage (control: 0.49 ), 0.48 to 0.62 in young fruit stage (control: 0.52 ), 0.45 to 0.57 in green ripe fruit stage (control: 0.48 ), and 0.21 to 0.26 in red ripe fruit stage (control: 0.22) (Table 3). Unlike chlorophyll content, the PR $\left(\mu \mathrm{M} \mathrm{CO} / \mathrm{m}^{2} / \mathrm{s}\right)$ of $c t b$ transgenic plants was relatively different, they range from 7.94 to 14.89 in branching stage (control: 12.76), 8.94 to 16.38 in flowering stage (control: 15.01), and 9.08 to 16.77 in young fruit stage (control: 15.42), where transgenic plants \#3 and \#4 had the lowest PR. During the two ripening stages of tomato, the PR of the transgenic and control plants was not significantly different (Table 4).
Table-4. Photosynthetic rate $\left(\mu \mathrm{M} \mathrm{CO} 2 / \mathrm{m}^{2} / \mathrm{s}\right)$ of $c t b$ transgenic tomato plants compared with control (non-transgenic tomato plant)

\begin{tabular}{|c|c|c|c|c|c|c|c|c|}
\hline \multirow{2}{*}{ Stages } & \multicolumn{6}{|c|}{ Transgenic plants } & \multirow{2}{*}{ Control } & \multirow{2}{*}{ LSD $_{0.0}$} \\
\hline & 1 & 2 & 3 & 4 & 5 & 6 & & \\
\hline Branching & $10.67^{\mathrm{bc}}$ & $14.64^{\mathrm{a}}$ & $8.69^{\mathrm{cd}}$ & $7.94^{\mathrm{d}}$ & $13.16^{\mathrm{ab}}$ & $14.89^{\mathrm{a}}$ & $12.76^{\mathrm{ab}}$ & 2.15 \\
\hline Flowering & $12.76^{\mathrm{b}}$ & $15.14^{\mathrm{ab}}$ & $9.18^{\mathrm{c}}$ & $8.94^{\mathrm{c}}$ & $14.52^{\mathrm{ab}}$ & $16.38^{\mathrm{a}}$ & $15.01^{\mathrm{ab}}$ & 1.98 \\
\hline $\begin{array}{c}\text { Young } \\
\text { fruit }\end{array}$ & 13. $40^{\mathrm{a}}$ & $16.38^{\mathrm{a}}$ & $9.68^{\mathrm{b}}$ & $9.08^{\mathrm{b}}$ & $16.08^{a}$ & $16.77^{\mathrm{a}}$ & $15.42^{\mathrm{a}}$ & 3.65 \\
\hline $\begin{array}{c}\text { Green ripe } \\
\text { fruit }\end{array}$ & $6.70^{\mathrm{a}}$ & $7.33^{\mathrm{a}}$ & $5.66^{\mathrm{a}}$ & $5.58^{\mathrm{a}}$ & $6.70^{\mathrm{a}}$ & $7.63^{\mathrm{a}}$ & $6.52^{\mathrm{a}}$ & 2.40 \\
\hline $\begin{array}{l}\text { Red ripe } \\
\text { fruits }\end{array}$ & $4.10^{\mathrm{a}}$ & $3.72^{\mathrm{a}}$ & $3.72^{\mathrm{a}}$ & $3.91^{\mathrm{a}}$ & $3.54^{\mathrm{a}}$ & $4.06^{\mathrm{a}}$ & $4.84^{\mathrm{a}}$ & 1.67 \\
\hline
\end{tabular}

Significant differences between mean values are represented by different letters in a row at confidence level of 0.05 of Duncan's test.

Data from Table 5 and Fig. 1 show that the yield, yield components and fruit shape of $c t b$ transgenic and control tomato plants are similar, except fruit number of transgenic plants \#3 and \#4 are relatively low. The fruit number of six transgenic plants range from 14.6 to 23 (control: 20.6), their fruit weight range from 61.5 to $69.3 \mathrm{~g}$ (control: $63.4 \mathrm{~g}$ ), and individual yield varies from 0.99 to $1.53 \mathrm{~kg}$ (control: $1.31 \mathrm{~kg})$.

Table-5. Yield and yield components of ctb transgenic tomato plants compared with control (non-transgenic tomato plant)

\begin{tabular}{|c|c|c|c|}
\hline $\begin{array}{c}\text { Transgenic } \\
\text { plants }\end{array}$ & $\begin{array}{c}\text { No of } \\
\text { fruits }\end{array}$ & $\begin{array}{c}\text { Fruit } \\
\text { weight (g) }\end{array}$ & $\begin{array}{c}\text { Individual } \\
\text { yield (kg) }\end{array}$ \\
\hline 1 & $19.6^{\mathrm{ab}}$ & $61.9^{\mathrm{ab}}$ & $1.21^{\mathrm{a}}$ \\
\hline 2 & $21.3^{\mathrm{ab}}$ & $66.6^{\mathrm{a}}$ & $1.42^{\mathrm{a}}$ \\
\hline 3 & $14.6^{\mathrm{b}}$ & $68.1^{\mathrm{a}}$ & $0.99^{\mathrm{ab}}$ \\
\hline 5 & $15.6^{\mathrm{b}}$ & $69.3^{\mathrm{a}}$ & $1.08^{\mathrm{ab}}$ \\
\hline 6 & $20.3^{\mathrm{ab}}$ & $61.5^{\mathrm{ab}}$ & $1.25^{\mathrm{a}}$ \\
\hline $\mathrm{Control}^{\mathrm{a}}$ & $23.0^{\mathrm{a}}$ & $66.4^{\mathrm{a}}$ & $1.53^{\mathrm{a}}$ \\
\hline $\mathrm{LSD}_{0.05}$ & 5.04 & 7.92 & 0.52 \\
\hline
\end{tabular}

Significant differences between mean values are represented by different letters in a column at confidence level of 0.05 of Duncan's test. 


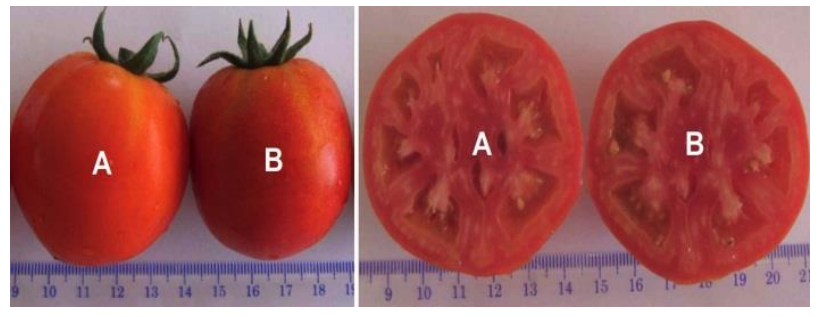

Figure-1. Tomato fruit shape is flattened of control plant (A) and $c t b$ transgenic plant (B).

\section{Biochemical characteristics}

Data from Table 6 show that almost the analyzed biochemical characteristics of six transgenic and control tomato plants are not different. Dry matter (\%) is from 5.45 to 5.91 (control: 5.62), reducing sugar (\%) is from 1.87 to 2.22 (control: 2.04), vitamin $\mathrm{C}(\mathrm{mg} / 100 \mathrm{~g})$ is from 44.32 to 46.13 (control: 44.01), acidity (\%) is from 0.62 to 0.89 (control: 0.82), Brix (\%) is from 5.23 to 6.01 (control: 5.89), and finally carotenoid $(\mathrm{mg} / 100 \mathrm{~g})$ from 3.01 to 3.84 (control: 3.66). CTB protein content of transgenic tomatoes reached a value of about $0.9 \%$ of total soluble protein as reported in a previous study (Loc et al., 2011).

Table-6. Tomato fruit quality of $c t b$ transgenic plants compared with control (non-transgenic tomato plant)

\begin{tabular}{|c|c|c|c|c|c|c|}
\hline $\begin{array}{c}\text { Transgenic } \\
\text { plants }\end{array}$ & $\begin{array}{c}\text { Dry } \\
\text { matter } \\
(\mathbf{\%})\end{array}$ & $\begin{array}{c}\text { Reducing } \\
\text { sugars } \\
(\mathbf{\%})\end{array}$ & $\begin{array}{c}\text { Vitamin C } \\
(\mathbf{m g} / \mathbf{1 0 0} \mathbf{g})\end{array}$ & $\begin{array}{c}\text { Acidity } \\
(\mathbf{\%})\end{array}$ & $\begin{array}{c}\text { Brix } \\
(\boldsymbol{\%})\end{array}$ & $\begin{array}{c}\text { Carotenoid } \\
(\mathbf{m g} / \mathbf{1 0 0} \mathbf{g})\end{array}$ \\
\hline 1 & $5.91^{\mathrm{a}}$ & $2.13^{\mathrm{a}}$ & $45.02^{\mathrm{b}}$ & $0.62^{\mathrm{ab}}$ & $5.74^{\mathrm{a}}$ & $3.62^{\mathrm{a}}$ \\
\hline 2 & $5.48^{\mathrm{a}}$ & $1.98^{\mathrm{a}}$ & $46.13^{\mathrm{a}}$ & $0.78^{\mathrm{a}}$ & $5.67^{\mathrm{a}}$ & $3.60^{\mathrm{a}}$ \\
\hline 3 & $5.45^{\mathrm{a}}$ & $2.22^{\mathrm{a}}$ & $44.57^{\mathrm{b}}$ & $0.81^{\mathrm{a}}$ & $5.23^{\mathrm{a}}$ & $3.01^{\mathrm{a}}$ \\
\hline 4 & $5.78^{\mathrm{a}}$ & $2.09^{\mathrm{a}}$ & $44.55^{\mathrm{b}}$ & $0.89^{\mathrm{a}}$ & $6.01^{\mathrm{a}}$ & $3.84^{\mathrm{a}}$ \\
\hline 5 & $5.82^{\mathrm{a}}$ & $1.87^{\mathrm{ab}}$ & $45.77^{\mathrm{a}}$ & $0.69^{\mathrm{a}}$ & $5.55^{\mathrm{a}}$ & $3.43^{\mathrm{a}}$ \\
\hline 6 & $5.45^{\mathrm{a}}$ & $1.95^{\mathrm{a}}$ & $44.32^{\mathrm{b}}$ & $0.71^{\mathrm{a}}$ & $5.72^{\mathrm{a}}$ & $3.55^{\mathrm{a}}$ \\
\hline Control $_{2} 5.62^{\mathrm{a}}$ & $2.04^{\mathrm{a}}$ & $44.01^{\mathrm{b}}$ & $0.82^{\mathrm{a}}$ & $5.98^{\mathrm{a}}$ & $3.66^{\mathrm{a}}$ \\
\hline LSD $_{0.05}$ & 0.61 & 0.54 & 0.88 & 0.30 & 1.12 & 1.01 \\
\hline
\end{tabular}

Significant differences between mean values are represented by different letters in a column at confidence level of 0.05 of Duncan's test.

\section{Discussion}

In a previous study, we found that there were no remarkable differences about root number and length or there were only slight differences about plant height and leaf number between ltb transgenic watercress (Nasturtium officinale) and control plant. In the whole, their physiological characteristics were also insignificantly different (Loc et al., 2015).
Before that, Wei et al. (2004) showed the PR of NADP-ME transgenic rice line and control rice plant were similar. Thiruveedhi (2006) indicated that chlorophyll and carotene content in AtGDH and GTA transgenic tobacco lines and control tobacco were also equivalent. According to Prematilake et al. (2002), the number of chloroplasts or stomatal guard cell pairs in $n p t I I$ transgenic tomato lines and control plants was not different. Several other reports showed no differences about morphology, growth rate and flowering time between transgenic and control plant such as transgenic cucumber resistant to Botrytis cinerea (Koga-Ban et al., 2004) or nptII transgenic tomato (Prematilake et al., 2002).

Investigation of some growth and morphological characteristics of Gus and nptII transgenic Solanum dulcamara plants showed that their plant height, length of stem nodal segment, length and width of leaf blade were insignificant different in comparison with control (Curtis et al., 2000). However, Shah et al. (2015) found that when treated with cold stress, the conductivity of stomata, the rate of evaporation and the relative water content in DREB1A transgenic tomatoes were significantly higher than the control plants.

Study of Baxter et al. (2015) showed that PvMYB4 transgenic switchgrass (Panicum virgatum) had important gains in both biofuel (more than 32\%) and biomass (more than 63\%) at the end of the second growing season compared to control plant. However, we did not find significant differences in biochemical characteristics such as contents of pigment, cellulose, vitamin $\mathrm{C}$, calcium and potassium of $l t b$ transgenic watercress compared to the control when were planted under natural condition (Loc et al., 2015). Xu et al. (2018) also obtained similar results from transgenic rice expressed Cry1Ab/Vip3A fused protein for insect resistance. Their agronomic characteristics such as plant height, panicles per plant, grains per panicle, weight of 100 grains and seed set rate showed insignificant differences in comparison with control rice plant.

\section{Conclusion}

From this investigation, we find that six $c t b$ transgenic tomato individuals with the normal phenotype did not substantially differ from nontransgenic control plants in their main agrobiological characteristics when were grown under in vivo condition such as farming time, individual yield and 
fruit quality. These results show a promising prospect for $c t b$ antigen production by genetically engineered tomatoes.

\section{Acknowledgment}

Authors acknowledge the support by Hue University, Hue, Vietnam for this project.

\section{Disclaimer: None.}

\section{Conflict of Interest: None.}

Source of Funding: This study was financed by Hue University, Hue, Vietnam.

\section{References}

Alvarez ML, Pinyerd H, Crisantes JD, Rigano MM, Pinkhasov J, Wamsley A, Mason HS and Cardineau GA, 2006. Plant-made subunit vaccine against pneumonic and bubonic plague is orally immunogenic in mice. Vaccine. 24: 2477-2490.

Baxter HL, Poovaiah CR, Yee KL, Mazarei M, Rodriguez Jr M, Thompson OA, Shen H, Turner GB, Decker SR, Sykes RW, Chen F, Davis MF, Mielenz JR, Davison BH, Dixon RA and Stewart $\mathrm{Jr} \mathrm{CN}, 2015$. Field evaluation of transgenic switchgrass plants overexpressing PvMYB4 for reduced biomass recalcitrance. Bioenerg. Res. 8: 910-921.

Beecher GR, 1998. Nutrient content of tomatoes and tomato products. Proc. Soc. Exp. Biol. Med. 218: 98-100.

Chen $\mathrm{Y}$ and $\mathrm{Xu}$ DQ, 2007. Changes in leaf photosynthesis of transgenic rice with silenced OsBP-73 gene. Photosynthetica. 45: 419-425.

Curtis IS, Power JB, Hedden H, Phillips A, Lowe KC, Ward DA and Davey RM, 2000. Transformation and characterization of transgenic plants of Solanum dulcamara L.incidence of transgene silencing. Ann. Bot. 86: 63-71.

De Toledo VdAA, Ruvolo-Takasusuki MCC, de Oliveira AJB, Chambo ED and Lopes SMS, 2012. Spectrophotometry as a Tool for Dosage Sugars in Nectar of Crops Pollinated by Honeybees. In: Macro To Nano Spectroscopy, Uddin J (ed.). In Tech, Rijeka, Croatia, pp. 269290.

FAO, 2019. Crops. FAOSTAT. Countries - Select All; Regions - World+(Total); Elements -
Production Quantity; Items - Tomatoes; Years 2017.

Field CB, Ball JT and Berry JA, 1989. Photosynthesis: principles and field techniques. In: Pearcy RW, Ehleringer JR, Mooney HA, Rundel PW (eds), Plant Physiological Ecology. Springer, Dordrecht, pp. 209-253.

Kantor M, Sestras R and Chowdhury K, 2013. Transgenic tomato plants expressing the antigen gene PfCP-2.9 of Plasmodium falciparum. Pesq. Agropec. Bras. 48: 73-79.

Kiełkiewicz M, Gajc-Wolska J, Slusarz S and Szwacka M, 2012. Growth, development and yield of transgenic 35S-thaumatin II-expressing cucumber plants-open field evaluation. Sci. Hortic. 143: 82-91.

Koga-Ban Y, Tabei Y, Ishimoto M, Nishizawa Y, Tsuchiya K, Imaizumi N, Nakamura H, Kayano $\mathrm{T}$ and Tanaka H, 2004. Biosafety assessment of transgenic plants in the greenhouse and the fields: a case study of transgenic cucumber. JARQ. 38: 167-174.

Li Y, He N, Hou J, Xu L, Liu C, Zhang J, Wang Q, Zhang $\mathrm{X}$ and $\mathrm{Wu} \mathrm{X}, 2018$. Factors influencing leaf chlorophyll content in natural forests at the biome scale. Front. Ecol. Evol. 6:64. doi: 10.3389/fevo.2018.00064.

Lichtenthaler HK and Buschmann C, 2001. Chlorophylls and Carotenoids: Measurement and Characterization by UV-VIS Spectroscopy. pp. F4.3.1-F4.3.8. In R.E. Wrolstad, T.E. Acree, H. An, E.A. Decker, M.H. Penner, D.S. Reid, S.J. Schwartz, C.F. Shoemaker and P. Sporns (eds.), Current Protocols in Food Analytical Chemistry, John Wiley and Sons, New York, USA.

Lieman-Hurwitz J, Rachmilevitch S, Mittler R, Marcus Y and Kaplan A, 2003. Enhanced photosynthesis and growth of transgenic plants that express ictB, a gene involved in $\mathrm{HCO}_{3}{ }^{-}$ accumulation in cyanobacteria. Plant Biotechnol. J. 1: 43-50.

Loc NH, Thinh LT, Yang MS and Kim TG, 2011. Highly expressed cholera toxin B subunit in the fruit of a transgenic tomato (Lycopersicon esculentum L.). Biotechnol. Bioproc. E. 16: 576580.

Loc NH, Long DT, Kim TG and Yang MS, 2014. Expression of Escherichia coli heat-labile enterotoxin B subunit in transgenic tomato (Lycopersicon esculentum L.) fruit. Czech J. Genet. Plant Breed. 50: 26-31. 
Loc NH, Song NV, Long DT, Kim TG and Yang MS, 2015. In vivo evaluation of transgenic watercress containing gene encoding Escherichia coli heat-labile toxin B subunit. J. Plant Biochem. Biotechnol. 24: 129-134.

Njoku PC, Ayuk AA and Okoye CV, 2011. Temperature effects on vitamin $\mathrm{C}$ content in citrus fruits. Pak. J. Nutr. 10: 1168-1169.

Passam HC, Karapanos IC, Bebeli PJ and Savvas D, 2007.A review of recent research on tomato nutrition, breeding and post-harvest technology with reference to fruit quality. Eur. J. Plant Sci. Biotechnol. 1: 1-21.

Perea Arango I, Loza Rubio E, Rojas Anaya E, Olivera Flores T, Gonzalez de la Vara L and Gomez Lim MA, 2008. Expression of the rabies virus nucleoprotein in plants at high-levels and evaluation of immune responses in mice. Plant Cell Rep. 27: 677-685.

Prematilake DP, Power JB and Davey MR, 2002. Genetic transformation of cultivated tomato (Lycopersicon esculentum) with Agrobacterium. Ann. Sri Lanka Dept. Agric. 4: 207-214.

Rawat P, Singh AK, Ray K, Chaudhary B, Kumar S, Gautam T, Kanoria S, Kaur G, Kumar P, Pental $\mathrm{D}$ and Burma PK, 2011. Detrimental effect of expression of $\mathrm{Bt}$ endotoxin $\mathrm{Cry} 1 \mathrm{Ac}$ on in vitro regeneration, in vivo growth and development of tobacco and cotton transgenics. J. Biosci. 36: 363-376.

Reinecke DM, Wickramarathna AD, Ozga JA, Kurepin LV, Jin AL, Good AG and Pharis RP, 2013. Gibberellin 3-oxidase gene expression patterns influence gibberellin biosynthesis, growth, and development in pea. Plant Physiol. 163: 929-945.

Sadler GD and Murphy PA, 2010. pH and Titratable Acidity. In: Nielsen SS (ed), Food Analysis. Springer, pp. 219-239.

Shah SH, Ali S, Jan SA, Din JU and Ali GM, 2015. Piercing and incubation method of in planta transformation producing stable transgenic plants by overexpressing DREBIA gene in tomato
(Solanum lycopersicum Mill.). Plant Cell Tiss. Organ Cult. 120: 1139-1157.

Soria-Guerra RE, Rosales-Mendoza S, MarquezMercado C, Lopez-Revilla R, Castillo-Collazo R and Alpuche-Solis AG, 2007. Transgenic tomatoes express an antigenic polypeptide containing epitopes of the diphtheria, pertussis and tetanus exotoxins, encoded by a synthetic gene. Plant Cell Rep. 26: 961-968.

Thiruveedhi K, 2006. Molecular and biochemical analyses of transgenic Nicotiana tabacum plants metabolizing glycolate in the chloroplasts. Ph.D. dissertation, Institute for Biology I (Botany and Molecular Genetics) RWTH Aachen University, Deutsch.

Srinivas L, Kumar GBS and Ganapathi TR, 2008. Transient and stable expression of hepatitis B surface antigen in tomato (Lycopersicon esculentum L.). Plant Biotechnol. Rep. 2: 1-6.

Wang GK, Zhang M, Gong JF, Guo QF, Feng YN and Wang W, 2012. Increased gibberellin contents contribute to accelerated growth and development of transgenic tobacco overexpressing a wheat ubiquitin gene. Plant Cell Rep. 31: 2215-2227.

Wei C, Jing-Song Z, Fang Z and Nai-Hu W, 2004. Photosynthetic features of transgenic rice expressing sorghum C4 type NADP-ME. Acta Bot. Sin. 467: 873-882.

$\mathrm{Xu} \mathrm{C}$, Cheng J, Lin H, Lin C, Gao J and Shen Z, 2018. Characterization of transgenic rice expressing fusion protein Cry1Ab/Vip3A for insect resistance. Sci. Rep. 8: 15788. doi:10.1038/s41598-018-34104-4.

\section{Contribution of Authors}

Loc NH: Designed research methodology, processed and analysed experimental data and wrote the manuscript

Thinh LT: Conducted the research work, collected data and participated in manuscript write up 